\title{
Pengaruh Gaya Hidup dan Citra Merek Terhadap Keputusan Pembelian Smartphone Xiaomi di Kabupaten Buleleng
}

\author{
Novia Sriwahyuni ${ }^{\star 1}$, Ni Luh Wayan Sayang Telagawathi ${ }^{2}$ \\ 1,2Program Studi Manajemen \\ Universitas Pendidikan Ganesha \\ Singaraja, Indonesia
}

\begin{abstract}
e-mail: noviasriwahyuni05@undiksha.ac.id¹, gemilangsuryawan@gmail.com²
\end{abstract}

Riwayat Artikel
Tanggal diajukan:
24 Februari 2021
Tanggal diterima :
24 Mei 2021
Tanggal
dipublikasikan:
25 Juni 2021

Pengutipan: Sriwahyuni. N \& Telagawathi, N. L. W. S. (2021). Pengaruh Gaya Hidup Dan Citra Merek Terhadap Keputusan Pembelian Smartphone Xiaomi Di Kabupaten Buleleng. Jurnal Pendidikan Ekonomi Undiksha, 13(1), 152-163 http://dx.doi.org/1 0.23887/jipe.v13i 1.32612

\begin{abstract}
Abstrak
Penelitian ini bertujuan untuk menganalisis pengaruh dari gaya hidup dan citra merek secara simultan dan secara parsial terhadap keputusan pembelian smartphone Xiaomi di Kabupaten Buleleng. Rancangan penelitian yang digunakan pada penelitian ini adalah penelitian kuantitatif kausal. Penelitian ini merupakan penelitian sampel dengan penentuan sampel yang digunakan adalah accidental sampling. Jumlah sampel yang digunakan adalah 100 orang responden. Instrument penelitian yang digunakan dalam pengumpulan data adalah kuesioner dan dengan teknik analisis data yang digunakan adalah analisis regresi linier berganda. Hasil dari penelitian ini adalah: 1) Gaya hidup berpengaruh positif dan signifikan terhadap keputusan pembelian smartphone Xiaomi di Kabupaten Buleleng, 2) Citra Merek berpengaruh positif dan signifikan terhadap keputusan pembelian smartphone Xiaomi di Kabupaten Buleleng, serta 3) Gaya hidup dan citra merek berpengaruh signifikan terhadap keputusan pembelian smartphone Xiaomi di Kabupaten Buleleng.
\end{abstract}

Kata Kunci: citra merek, gaya hidup, keputusan pembelian.

\begin{abstract}
The objective of this research is to analyze the influence of lifestyle and brand image simultaneously and partially on purchasing decisions for Xiaomi smartphones in Buleleng Regency. The research framework used in this research is causal quantitative. The sample used in this research determined through accidental sampling. The number of samples used was 100 respondents. The research instrument used in data collection was a questionnaire and the data analysis technique done by using multiple linear regression analysis. The result of this research are: 1) lifestyle has a positive and significant effect on purchasing decisions for Xiaomi smartphones in Buleleng Regency, 2) Brand image has a positive and significant effect on purchasing decisions for Xiaomi smartphones in Buleleng Regency, and 3) Lifestyle and brand image have a significant effect on purchasing decisions for Xiaomi smartphones in Buleleng Regency.
\end{abstract}

Keywords: brand image, lifestyle, purchasing decision. 
p-ISSN : 2599-1418

e-ISSN : 2599-1426

\section{PENDAHULUAN}

Smartphone telah menjadi kebutuhan pokok masyarakat pada masa ini. Mengutip dari tribunnews.com yang menyatakan bahwa smartphone memiliki peran penting saat ini yaitu memudahkan komunikasi jarak jauh, memperoleh berita atau informasi dengan cepat dan akurat, smartphone memiliki fitur kamera yang sangat membantu dalam mengabadikan momen tanpa harus memiliki kamera digital, memperoleh hiburan kapanpun dan dimanapun, dan dapat membantu saat bepergian ke daerah yang belum pernah dikunjungi dengan menggunakan fitur Global Positioning System (GPS). Manfaatmanfaat tersebut hanya rangkuman dari sekian banyak manfaat smartphone pada saat ini. Kegunaan lain smartphone yang sangat penting yaitu melalui smartphone, masyarakat dapat mengakses pelajaran dari manapun dan kapanpun bagi para siswa dan mahasiswa serta dapat melakukan pertemuan atau rapat hanya melalui smartphone saja.

Pada tahun 2017 Kenmentrian Komunikasi dan Informatika (Kominfo) melaksanakan survey penggunaan TIK yang melibatkan 9.419 responden (4.945 orang laki-laki dan 4.474 orang perempuan) dari 34 Provinsi, rentang usia 9 hingga 65 tahun, berbagai macam pekerjaan dan jenjang pendidikan, serta besar pengeluaran (Kominfo, 2017). Dari hasil survei tersebut dapat diketahui bahwa lebih dari setengah penduduk Indonesia telah menggunakan smartphone yaitu sebesar $66,31 \%$ dari jumlah penduduk. Laki-laki yang menggunakan smartphone lebih banyak dibandingkan perempuan dengan persentase $67,41 \%$. Apabila dilihat berdasarkan usia, yang memiliki persentase tertinggi pada sub-kategorinya adalah penduduk dengan usia 20 - 29 tahun dengan persentase $75,95 \%$. Berdasarkan pendidikan, tidak sekolah memiliki persentase 21,08\%; SD 40,87\%; SMP 59,89\%; SMA 79,93\%; Diploma/S1 93,02\%; serta S2/S3 $100 \%$ hal ini menunjukkan bahwa semakin tinggi jenjang pendidikan, maka semakin tinggi pula persentase
Jurnal Pendidikan Ekonomi Undiksha

Vol. 13 No. 1 (2021)

penggunaan smartphone. Begitu pula pada besar pengeluaran, semakin besar pengeluaran maka semakin besar pula persentase penggunaan smartphone. Jenis pekerjaan juga mempengaruhi penggunaan smartphone, dari hasil survei dapat diketahui bahwa PNS/TNI/Polri memiliki persentase tertinggi yaitu $89,12 \%$ yang kemudian disusul oleh jenis pekerjaan karyawan swasta dengan persentase $87,78 \%$

Berdasarkan hasil survey yang dilakukan Kominfo tersebut, secara keseluruhan dapat disimpulkan bahwa fenomena penggunaan smartphone dipengaruhi oleh gaya hidup. Kotler \& Keller (2018) menyatakan bahwa "gaya hidup merupakan pola hidup seseorang yang terungkap pada aktivitas, minat dan opininya. Gaya hidup menggambarkan keseluruhan diri seseorang yang berinteraksi dengan lingkungannya. Gaya hidup seseorang terbentuk melalui keterbatasan yaitu keterbatasan uang atau keterbatasan waktu". Dapat dilihat dengan jelas bahwa semakin besar pengeluaran seseorang maka semakin besar pula persentase penggunaan smartphone dan semakin tinggi jenjang pendidikan semakin tinggi pula penggunaan smartphone. Dapat disimpulkan bahwa semakin tinggi jenjang pendidikan semakin besar pengeluaran maka semakin tinggi pula penggunaan smartphone, hal ini menunjukkan batasan uang yang dimiliki oleh seseorang yang mempengaruhi gaya hidup. Selain itu dalam survey tersebut dapat diketahui pula bahwa waktu penggunaan smartphone paling banyak adalah $1-3$ jam perhari dan tingkan persentase yang berbeda dalam tiap jenis pekerjaan menunjukkan batasan waktu yang dimiliki oleh seseorang yang mempengaruhi gaya hidup.

Salah satu jenis handphone yang berkembang saat ini adalah handphone dengan merek Xiaomi yang diluncurkan oleh Xiaomi Corporation. Xiaomi saat ini adalah merek smartphone terbesar keempat di dunia. Saat ini, produk Xiaomi hadir di lebih dari 90 negara dan wilayah di 
p-ISSN : 2599-1418

e-ISSN : 2599-1426

seluruh dunia serta memiliki pijakan terdepan di banyak pasar (Mi.com., 2020). Smartphone Xiaomi resmi masuk ke pasar Indonesia pada tahun 2014 dan mampu bersaing dalam pasar Indonesia secara kompetitif. Hal ini dibuktikan dengan data Top Brand Index. Data Top Brand Index dapat di percaya keandalannya karena reponden dalam survei yang dilakukan berasal dari berbagai kota besar dengan jumlah sampel yang besar, selain itu pihak peyelenggara melakukan wawancara secara tatap muka dan menggunakan kuesioner terstruktur yang didesain khusus untuk mengukur tiga parameter Top Brand yaitu Top of Mind, Last Usage dan Future Intentions. Top of mind yaitu kesadaran
Jurnal Pendidikan Ekonomi Undiksha

Vol. 13 No. 1 (2021)

akan merek (merek pertama yang disebutkan oleh responden saat kategori produk diutarakan). Last Usage yaitu penggunaan terakhir (merek terakhir yang digunakan atau dikonsumsi oleh responden dalam siklus pembelian ulang). Future intention yaitu niat membeli kembali (keinginan responden untuk menggunakan/mengkonsumsi kembali di masa mendatang). Top Brand Index (TBI) diperoleh dengan cara menghitung rata-rata terbobot masing-masing parameter. Top Brand Award diberikan kepada sebuah merek apabila memiliki TBI minimum 10\% dan menurut hasil survei, merek tersebut menempati posisi tiga teratas dalam kategori produk.

Tabel 1. Top Brand Index Fase 1 Kategori Smartphone Tahun 2017 - 2020

\begin{tabular}{lll}
\hline Tahun & Brand & Brand Index \\
\hline 2017 & Samsung & $46,4 \%$ \\
& Oppo & $4,1 \%$ \\
2018 & Xiaomi & - \\
& Samsung & $48,6 \%$ \\
& Oppo & $11,2 \%$ \\
2019 & Xiaomi & $5,5 \%$ \\
& Samsung & $45,8 \%$ \\
2020 & Oppo & $16,6 \%$ \\
& Xiaomi & $14,3 \%$ \\
& Samsung & $46,5 \%$ \\
& Oppo & $17,7 \%$ \\
\hline
\end{tabular}

(Sumber: Situs resmi Top Brand Award)

Tabel 2. Top Brand For Teens Index Kategori Smartphone Tahun 2017 - 2020

\begin{tabular}{lll}
\hline Tahun & Brand & Brand Index \\
\hline 2017 & Samsung & $38,2 \%$ \\
& Oppo & $9,5 \%$ \\
2018 & Xiaomi & $7,8 \%$ \\
& Samsung & $43,50 \%$ \\
2019 & Oppo & $12,47 \%$ \\
& Xiaomi & $13,05 \%$ \\
2020 & Samsung & $46,1 \%$ \\
& Oppo & $15,0 \%$ \\
& Xiaomi & $11,4 \%$ \\
& Samsung & $46,0 \%$ \\
\hline
\end{tabular}


p-ISSN : 2599-1418

e-ISSN : 2599-1426

(Sumber: Situs resmi Top Brand Award)

Smartphone Xiaomi pada Tahun 2017 masuk dalam Top Brand For Teens Kategori Smartphone diurutan ke 4 dengan persentase $7,8 \%$ kemudian di tahun 2018 pada kategori yang sama meningkat ke urutan ke 3 dengan persentase 13,05\%. Pada tahun yang sama smartphone Xiaomi juga masuk dalam Top Brand Fase 1 di urutan ke 3 dengan persentase 5,5\%. Pada tahun 2019 smartphone Xiaomi mengalami penurunan persentase pada Top Brand For Teens yaitu dari $13,05 \%$ menjadi $11,4 \%$ namun mengalami peningkatan yang signifikan pada Top Brand yaitu dari 5,5\% menjadi $14,5 \%$ dan berada pada posisi yang sama yaitu urutan ke 3. Di tahun 2020 pada kategori Top Brand For Teens mengalami sedikit peningkatan yaitu dari $11,4 \%$ menjadi $11,6 \%$ sedangkan pada kategori Top Brand mengalami penurunan dari $14,5 \%$ menjadi $10,1 \%$ dengan posisi yang sama pada kedua kategori yaitu urutan ke 3. Dari data-data yang telah disampaikan dapat dikatakan bahwa tingkat persentase dari Xiaomi mengalami fluktuasi, sehingga perlu diketahui faktor yang mempengaruhi naik turunnya angka tersebut. Faktor-faktornya adalah perilaku pembelian konsumen dan citra merek smartphone Xiaomi yang berkaitan dengan keputusan pembelian.

Berdasarkan fenomena diatas, keberhasilan smartphone Xiaomi untuk masuk dalam kategori top brand dipengaruhi oleh keputusan pembelian. Merujuk pada penelitian-penelitian terdahulu sebagai studi empiris, Setyaningsih (2020) menyatakan bahwa keputusan pembelian dipengaruhi oleh citra merek, gaya hidup hedonis, dan harga. Halim \& Dinaroe (2019) menyatakan bahwa keputusan pembelian dipengaruhi oleh lifestyle, money attitude, dan personal value. Permana (2019) juga menyatakan bahwa keputusan pembelian dipengaruhi oleh citra merek, harga, word of mouth, dan gaya hidup. Menurut Supangkat \& Supriyatin (2017) menyatakan bahwa keputusan pembelian dipengaruhi oleh citra
Jurnal Pendidikan Ekonomi Undiksha

Vol. 13 No. 1 (2021)

merek, kualitas produk, dan harga. Berdasarkan fenomena dan studi empiris penelitian ini mengangkat gaya hidup dan citra merek sebagai variabel bebas dan keputusan pembelian sebagai variabel terikat.

Keputusan pembelian smartphone Xiaomi sangat dipengaruhi oleh gaya hidup konsumen. Hal ini didukung oleh data dari survei yang dilakukan oleh Kominfo dan telah dipaparkan sebelumnya. Sejalan pula dengan hasil dari penelitian terdahulu yang dilakukan oleh Somantri (2020) menyatakan bahwa gaya hidup dan citra merek berpengaruh secara parsial dan simultan terhadap keputusan pembelian. Halim \& Dinaroe (2019) menyatakan bahwa lifestyle, money attitude, dan personal value berpengaruh secara parsial terhadap keputusan pembelian. Permana (2019), menyatakan bahwa citra merek, harga, word of mouth, dan gaya hidup secara parsial berpengaruh terhadap keputusan pembelian. Namun hal berbeda diperoleh dalam hasil penelitian Giovinda \& Frista (2020) yang menyatakan bahwa gaya hidup tidak berpengaruh terhadap keputusan pembelian sedangkan variabel lainnya seperti harga dan promosi berpengaruh terhadap keputusan pembelian.

Keputusan pembelian smartphone Xiaomi juga diperuhi oleh citra merek dari smartphone Xiaomi sendiri. Citra merek smartphone Xiaomi saat ini adalah "smartphone murah" dengan spesifikasi dan performa juara. Citra inilah yang membawa Xiaomi masuk dalam deretan top brand di Indonesia kurang dari 5 tahun sejak masuknya ke pasar Indonesia seperti yang telah dipaparkan sebelumnya. Merujuk pada penelitian terdahulu, Setyaningsih (2020) menyatakan bahwa citra merek, gaya hidup hedonis, dan harga secara parsial berpengaruh positif dan signifikan terhadap keputusan pembelian. Permana (2019) menyatakan bahwa citra merek, harga, word of mouth, dan gaya hidup secara parsial berpengaruh terhadap keputusan pembelian. Sejalan dengan penelitian Supangkat \& Supriyatin (2017) 
yang menyatakan bahwa citra merek, kualitas produk, dan harga secara parsial berpengaruh positif dan signifikan terhadap keputusan pembelian. Namun hasil berbeda dinyatakan dalam penelitian Setiawan (2020) bahwa citra merek secara parsial tidak berpengaruh signifikan terhadap keputusan pembelian, sedangkan variabel lain yaitu atribut produk berpengaruh signifikan dan dominan terhadap keputusan pembelian. Hal serupa dengan setiawan juga diperoleh dalam penelitian Telagawathi (2019) yang menyatakan bahwa citra merek tidak berpengaruh terhadap keputusan pembelian sedangkan variabel promosi berpengaruh positif dan signifikan terhadap keputusan pembelian.

Kotler \& Keller (2018) menyatakan bahwa gaya hidup adalah pola hidup seseorang yang terungkap pada aktivitas, minat dan opininya. Gaya hidup menggambarkan keseluruhan diri seseorang yang berinteraksi dengan lingkungannya. Gaya hidup merupakan salah satu bentuk perilaku konsumen yang memengaruhi keputusan pembelian. Gaya hidup merupakan salah satu faktor pribadi yang memengaruhi perilaku pembelian konsumen (Kotler \& Armstrong, 2008). Melalui aktivitas yang dilakukan, minat dan opini yang dimiliki oleh konsumen, konsumen menentukan keputusan pembelian yang akan dilakukan. Hal ini sesuai dengan hasil penelitian yang dilakukan oleh Somantri (2020), Halim \& Dinaroe (2019) yang menyatakan bahwa gaya hidup berpengaruh positif dan signifikan terhadap keputusan pembelian.

Tjiptono \& Diana (2016) yang menyatakan bahwa citra merek berkenaan dengan persepsi konsumen terhadap sebuah merek. Elemen citra merek terdiri atas persepsi, kognisi, dan sikap. Sedangkan menurut Setiadi (dalam Permana, 2019) menyatakan bahwa "citra terhadap merek berhubungan dengan sikap yang berupa keyakinan dan preferensi terhadap suatu merek. Konsumen yang memiliki citra yang positif terhadap suatu merek akan lebih memungkinkan untuk melakukan pembelian. Citra merek terjadi karena adanya keyakinan konsumen yang akan memperoleh kualitas yang sama jika membeli ulang pada merek yang sama dengan yang dibeli sebelumnya". Hal ini sejalan dengan penelitian yang dilakukan oleh Setyaningsih (2020), Somantri (2020), Permana (2019) serta Supangkat \& Supriyatin (2017) yang menyatakan dalam hasil penelitiannya bahwa citra merek berpengaruh positif dan signifikan terhadap keputusan pembelian.

Keputusan pembelian merupakan salah satu perilaku konsumen yang sangat diperhatikan oleh pemasar. Tjiptono (2015) menyatakan bahwa keputusan pembelian merupakan suatu proses dalam perilaku konsumen yang dimulai dari identifikasi masalah atau kebutuhan konsumen yang dapat dipecahkan melalui pembelian produk tertentu kemudian konsumen mencari informasi tentang produk atau merek tertentu dan mengevaluasi seberapa baik masing-masing alternatif tersebut dapat memecahkan masalahnya dan evaluasi tersebut akan mengarah kepada keputusan pembelian. Menurut Philip Kotler \& Armstrong (2008) menyatakan bahwa perilaku pembelian konsumen dipengaruhi oleh faktor-faktor budaya, sosial, pribadi, dan psikologis. Gaya hidup merupakan salah satu faktor pribadi yang memengaruhi keputusan pembelian konsumen. Selain gaya hidup, citra merek juga berpengaruh pada keputusan pembelian konsumen. Tjiptono \& Diana (2016) yang menyatakan bahwa citra merek berkenaan dengan persepsi konsumen terhadap sebuah merek. Hal ini sejalan dengan hasil penelitian dari Somantri (2020) yang menyatakan bahwa gaya hidup dan citra merek secara simultan berpengaruh positif dan signifikan terhadap keputusan pembelian.

Tujuan dari penelitian ini adalah untuk, 1) menguji pengaruh gaya hidup terhadap keputusan pembelian smartphone Xiaomi di Kabupaten Buleleng. 2) Menguji pengaruh citra merek terhadap keputusan pembelian smartphone Xiaomi di Kabupaten Buleleng. 3) Menguji pengaruh gaya hidup dan citra merek terhadap 
p-ISSN : 2599-1418

e-ISSN : 2599-1426

keputusan pembelian smartphone Xiaomi di Kabupaten Buleleng.

\section{METODE}

Jenis metode penelitian yang digunakan dalam penelitian ini adalah metode penelitian kuantitatif. Metode penelitian kuantitatif merupakan metode penelitian yang berlandaskan pada filsafat positivisme, digunakan untuk meneliti pada populasi atau sampel tertentu, teknik pengambilan sampel pada umumnya dilakukan secara random, pengumpulan data menggunakan instrument penelitian, analisis data bersifat kuantitatif/statistik dengan tujuan untuk menguji hipotesis yang telah ditetapkan (Sugiyono, 2013). Desain penelitian yang digunakan dalam penelitian ini adalah penelitian kausal. Desain kausal digunakan untuk mengkaji hubungan sebab akibat antara variabel yang mempengaruhi dan variabel yang dipengaruhi (Sugiyono, 2013). Dalam penelitian ini, variabel yang mempengaruhi atau variabel bebas adalah gaya hidup $\left(X_{1}\right)$ dan citra merek $\left(X_{2}\right)$, sedangkan variabel yang dipengaruhi atau variabel terikat adalah keputusan pembelian (Y). Untuk menguji pengaruh gaya hidup dan citra merek terhadap keputusan pembelian digunakan analisis regresi linier berganda. Tahapan dalam desain penelitian kuantitatif kausal terdiri dari, merumuskan masalah, (2) mengkaji teori,

\section{(3)} merumuskan

hipotesis,

mengumpulkan data, (5) mengolah data, dan (6) menarik kesimpulan.

Populasi dalam penelitian ini yaitu masyarakat di Kabupaten Buleleng yang menggunakan smartphone Xiaomi. Sampel yang diambil menggunakan teknik non probability sampling yaitu sampling incidental. Pertimbangan untuk menentukan cocok atau tidaknya seseorang sebagai sampel penelitian ini berdasarkan kriteria berikut: 1) Memiliki dan menggunakan smartphone Xiaomi minimal selama 6 bulan, 2) Calon responden merupakan masyarakat di Kabupaten Buleleng, 3) Calon responden sedang berada di rentang usia 17 hingga 45 tahun dengan pertimbangan bahwa responden telah
Jurnal Pendidikan Ekonomi Undiksha

Vol. 13 No. 1 (2021)

dianggap dewasa dan mampu menjawab pertanyaan maupun pernyataan yang diajukan oleh peneliti. Dalam penelitian ini, jumlah sampel yang ditetapkan adalah 100 responden untuk dapat memperoleh data yang lebih bervariasi.

Metode pengumpulan data yang digunakan dalam penelitian ini adalah kuesioner atau angket. Jenis kuesioner yang digunakan dalam penelitian ini adalah kuesioner berstruktur (angket tertutup), dengan kemungkinan jawaban pernyataan yang telah disiapkan dalam bentuk pilihan. Responden tidak perlu lagi memberikan tambahan jawaban, responden hanya tinggal memilih salah satu alternatif dari lima jawaban yang sudah tersedia, yang nantinya dapat memudahkan penelitian dalam mengelola dan menganalisis data. Salah satu skala yang umum dipakai dalam penyusunan angket adalah Skala Likert, yaitu skala yang berisi lima tingkat jawaban yang disusun dalam bentuk suatu pernyataan dan diikuti oleh lima respon yang menunjukan tingkatan.

Sebelum data diolah ke analisis regresi linier berganda, terlebih dahulu data harus diuji dengan uji asumsi klasik, karena syarat untuk analisis regresi linier berganda adalah bebas dari asumsi-asumsi klasik. Uji asumsi klasik dilakukan sebelum menguji dan menganalisis data penelitian dengan model regresi dengan bantuan program Statistical Package for Social Science (SPSS) 25.0 for Windows. Adapun uji asumsi klasik tersebut meliputi: 1) uji normalitas yang digunakan untuk menguji apakah dalam model regresi, variabel pengganggu atau residual memiliki distribusi normal. 2) Uji multikolinieritas bertujuan untuk menguji apakah model regresi ditemukan adanya korelasi antar variabel bebas. 3) Uji Heteroskedastisitas digunakan untuk menguji apakah dalam model regresi terjadi ketidaksamaan variance dari residual satu pengamatan ke pengamatan yang lain.

Alat analisi yang digunakan dalam penelitian ini adalah analisi regresi linier berganda, karena dalam penelitian ini peneliti menguji pengaruh dari beberapa 
p-ISSN : 2599-1418

e-ISSN : 2599-1426

variabel bebas yaitu gaya hidup $\left(\mathrm{X}_{1}\right)$ dan citra merek $\left(X_{2}\right)$ terhadap satu variabel terikat yaitu keputusan pembelian (Y). Pengujian hipotesis menggunakan uji $F$ (uji simultan) dan Uji t (uji parsial). Uji statistik $F$ digunakan untuk menunjukan apakah semua variabel bebas (independen) yang dimasukan dalam model mempunyai pengaruh secara bersama-sama terhadap variabel terikat (dependen). Uji statistik $t$ menunjukan seberapa jauh pengaruh variabel penjelas/independen secara individual dalam menerangkan variasi variabel dependen (Ghozali, 2018). Uji t digunakan untuk menguji signifikansi variasi hubungan antara variabel $\mathrm{X}$ dan $\mathrm{Y}$, apakah
Jurnal Pendidikan Ekonomi Undiksha

Vol. 13 No. 1 (2021)

variabel gaya hidup $\left(\mathrm{X}_{1}\right)$ dan citra merek $\left(X_{2}\right)$ benar-benar berpengaruh secara parsial terhadap variabel keputusan pembelian $(Y)$.

\section{HASIL DAN PEMBAHASAN}

Pengolahan data dilakukan dengan bantuan program Statistical Package for Social Science (SPSS) 25.0 for Windows, yang digunakan untuk mengetahui ada tidaknya pengaruh variabel bebas gaya hidup dan citra merek terhadap variabel terikat keputusan pembelian. Sehingga diperoleh hasil pengujian berupa ringkasan hasil output SPSS. Hasil pengolahan data dapat dilihat pada Tabel 3.

Tabel 3. Ringkasan Output SPSS Analisis Regresi Linier Berganda

\begin{tabular}{lcccc}
\hline Variabel Bebas & Koefisien & Sig. & Koefisien Korelasi & $\mathrm{R}^{2}$ \\
\hline Gaya Hidup & 0,856 & 0,000 & 0,604 & 0,365 \\
Citra Merek & 0,232 & 0,026 & 0,224 & 0,050 \\
Konstanta & 6,024 & & & \\
Sig. F & 0,000 & & & \\
$\mathrm{R}$ & 0,772 & & & \\
$\mathrm{R}^{2}$ & 0,595 & & & \\
\hline
\end{tabular}

Sumber: Hasil Output SPSS 25.0 For Windows Analisis Regresi Linier Berganda

Berdasarkan hasil uji regresi berganda pada Tabel 3 diperoleh hasil nilai konstanta $(\alpha)$ sebesar 6,024 . Nilai koefisien variabel gaya hidup $\left(\beta_{1}\right)$ sebesar 0,856 dan nilai koefisien variabel citra merek $\left(\beta_{2}\right)$ sebesar 0,232. Sehingga persamaan regresi dapat diformulasikan sebagai berikut.

$Y=\alpha+\beta_{1} X_{1}+\beta_{2} X_{2}+\varepsilon$

$Y=6,024+0,856 X_{1}+0,232 X_{2}+0,405$

Berdasarkan persamaan linier berganda tersebut, menunjukkan bahwa: 1) Konstanta sebesar 6,024 artinya bahwa apabila gaya hidup $\left(X_{1}\right)$ dan citra merek $\left(X_{2}\right)$ bernilai 0 , maka nilai dari keputusan pembelian (Y) adalah 6,024. 2) Nilai koefisien variabel gaya hidup $\left(\beta_{1}\right)$ sebesar 0,856 yang berarti bahwa gaya hidup berpengaruh positif terhadap keputusan pembelian ( $Y$ ). Hal ini mengandung arti bahwa setiap kenaikan gaya hidup satu satuan maka variabel keputusan pembelian meningkat sebesar 0,856 sehingga menjadi 6,880 (peroleh dari 6,024 +0,856), dengan asumsi bahwa bariabel bebas yang lainnya tetap. 3) Nilai koefisien variabel citra merek $\left(\beta_{2}\right)$ sebesar 0,232 yang berarti bahwa citra merek berpengaruh positif terhadap keputusan pembelian (Y). Hal ini mengandung arti bahwa setiap kenaikan gaya hidup satu satuan maka variabel keputusan pembelian meningkat sebesar 0,232 sehingga menjadi 6,256 (diperoleh dari 6,024 +0,232), dengan asumsi bahwa variabel bebas yang lainnya tetap.

Koefisien Determinasi $\left(R^{2}\right)$ digunakan untuk mengukur seberapa jauh kemampuan model dalam menerangkan variasi variabel terikat. Pada penelitian ini $\mathrm{R}^{2}$ menjelaskan seberapa besar pengaruh gaya hidup $\left(X_{1}\right)$, citra merek $\left(X_{2}\right)$ terhadap keputusan pembelian (Y). Besarnya hasil uji koefisien determinasi dapat dilihat dari nilai Adjusted $R$ Square sebesar 0,587 . Hasil tersebut 
p-ISSN : 2599-1418

e-ISSN : 2599-1426

berkisar antara 0 sampai dengan 1 yang berarti bahwa dalam penelitian ini gaya hidup dan citra merek berpengaruh terhadap keputusan pembelian sebesar $58,7 \%$ sedangkan sebesar $41,3 \%$ dipengaruhi oleh varibel lain yang tidak diteliti dalam penelitian ini.

Hipotesis $1(\mathrm{H} 1)$ pada penelitian ini adalah "Ada pengaruh gaya hidup terhadap keputusan pembelian smartphone Xiaomi di Kabupaten Buleleng". Berdasarkan rekapan hasil uji regresi linier berganda pada Tabel 4.4 menunjukkan hasil $\mathrm{Pyx}_{1}=0,604$ dengan p-value $0,000<A l p h a(\alpha) 0,05$ hal ini menyatakan bahwa menolak $\mathrm{H}_{0}$ yang berarti ada pengaruh positif dan signifikan dari gaya hidup $\left(X_{1}\right)$ terhadap keputusan pembelian ( $\mathrm{Y})$, dengan sumbangan pengaruh $\left(P^{2} \mathrm{yx}_{1}=0,365\right)$ sebesar $36,5 \%$. Sehingga dapat disimpulkan bahwa variabel gaya hidup berpengaruh dalam meningkatkan keputusan pembelian.

Hipotesis $2(\mathrm{H} 2)$ dalam penelitian ini adalah "Ada pengaruh citra merek terhadap keputusan pembelian smartphone Xiaomi di Kabupaten Buleleng". Berdasarkan rekapan hasil muji regresi linier berganda pada Tabel 4.4 menunjukkan hasil $\mathrm{Pyx}_{2}=0,224$ dengan $p$-value 0,026 < Alpha (a) 0,05 hal ini menyatakan bahwa menolak $\mathrm{H}_{0}$ yang berarti ada pengaruh positif dan signifikan dari citra merek $\left(\mathrm{X}_{2}\right)$ terhadap keputusan pembelian ( $\mathrm{Y})$, dengan sumbangan pengaruh $\left(P^{2} \mathrm{yx}_{2}=0,050\right)$ sebesar $5,0 \%$. Sehingga dapat disimpulkan bahwa variabel citra merek berpengaruh dalam meningkatkan keputusan pembelian.

Hipotesis $3(\mathrm{H} 3)$ dalam penelitian ini adalah "Ada pengaruh gaya hidup dan citra merek terhadap keputusan pembelian smartphone Xiaomi di Kabupaten Buleleng". Berdasarkan rekapan hasil pengujian regresi linier berganda pada Tabel 4.3 menunjukkan hasil $\mathrm{Ryx}_{1} \mathrm{x}_{2}=0,772$ dengan $p$-value $0,000<$ Alpha $(\alpha) 0,05$, yang menyatakan bahwa menolak $\mathrm{H}_{0}$ yang berarti ada pengaruh positif dan signifikan dari gaya hidup $\left(X_{1}\right)$ dan citra merek $\left(X_{2}\right)$ terhadap keputusan pembelian $(\mathrm{Y})$, dengan sumbangan pengaruh $\left(R^{2} \mathrm{yx}_{1} \mathrm{x}_{2}=0,595\right)$ sebesar $59,5 \%$. Hasil tersebut menunjukkan
Jurnal Pendidikan Ekonomi Undiksha

Vol. 13 No. 1 (2021)

bahwa sebesar 59,5\% keputusan pembelian $(Y)$ di pengaruhi oleh gaya hidup $\left(X_{1}\right)$ dan citra merek $\left(X_{2}\right)$. Sedangkan pengaruh variabel lain di luar gaya hidup $\left(\mathrm{X}_{1}\right)$ dan citra merek $\left(\mathrm{X}_{2}\right)$ adalah sebesar 40,5\%. Hal ini dapat disimpulkan bahwa variabel gaya hidup $\left(\mathrm{X}_{1}\right)$ dan citra merek $\left(X_{2}\right)$ secara bersama-sama berperan dalam meningkatkan keputusan pembelian (Y).

Berdasarkan hasil penelitian menyatakan bahwa variabel gaya hidup berpengaruh positif dan signifikan terhadap keputusan pembelian smartphone Xiaomi di Kabupaten Buleleng. Hal ini sesuai dengan teori yang dikemukakan oleh Kotler \& Keller (2018) yang menyatakan bahwa gaya hidup merupakan salah satu faktor pribadi yang mempengaruhi keputusan pembelian. Setiap keputusan pembelian yang dilakukan oleh konsumen tidak terlepas dari gaya hidupnya dalam memilih dan membeli produk tertentu. Konsumen cenderung memilih dan membeli produk yang memiliki manfaat sesuai kebutuhan dan dengan kualitas yang baik. Dalam memenuhi kebutuhan, perilaku pembelian konsumen dipengaruhi oleh karakteristik gaya hidup yaitu aktivitas, minat, dan opini.

Dalam hal aktivitas yaitu menyangkut pekerjaan konsumen, hobi, olah raga, hiburan, acara sosial, dan komunitas yang diikuti konsumen. Smartphone Xiaomi memiliki fitur berupa aplikasi yang dapat membantu konsumen dalam melakukan aktivitasnya seperti aplikasi $\mathrm{Mi}$ Remote yang berfungsi sebagai remote AC, TV, Kipas Angin, Proyektor, Kamera, dan Lain sebagainya. Dengan fitur ini, konsumen menjadi lebih mudah dalam menggunakan berbagai alat elektronik hanya dengan melalui satu smartphone saja. Selain itu, untuk memperoleh hiburan, smartphone Xiaomi memiliki aplikasi Music yang berfungsi untuk memutar musik secara offline maupun online, aplikasi ini telah terhubung langsung dengan JOOX yaitu aplikasi untuk mendengarkan musik. Sehingga konsumen tidak lagi memerlukan cukup ruang (RAM dan memori internal pada handphone) untuk menginstal aplikasi pemutar musik lainnya. 
p-ISSN : 2599-1418

e-ISSN : 2599-1426

Dalam hal minat yang berkaitan dengan kesukaan, kegemaran, dan prioritas dalam hidup konsumen yang bisa dipengaruhi oleh keluarga, mode, dan media. Seperti yang diketahui bahwa saat ini, masyarakat cenderung menyukai peralatan dengan teknologi terbaru. Smartphone Xiaomi hadir dengan teknologi terbaru yang digemari masyarakat yaitu fitur kamera. Fitur kamera pada smartphone Xiaomi saat ini memiliki beberapa pilihan seperti slow motion (gerak lambat), short video (video pendek) yang dilengkapi dengan back sound, video dan photo dengan perbesaran 0,6 kali, 1 kali, dan 2 kali, kamera $48 \mathrm{Mp} / 64 \mathrm{Mp}$, portrait, mode malam, panorama, dan pro. Pilihan-pilihan yang terdapat pada fitur kamera yang dimiliki oleh smartphone Xiaomi ini sangat membantu masyarakat yang memiliki minat pada bidang photography karena tidak lagi perlu membeli kamera digital.

Opini masyarakat terbentuk dari pengalaman yang dialami langsung maupun yang dialami oleh orang lain. Beberapa opini masyarakat yang terbentuk menganai smartphone Xiaomi adalah memiliki kamera canggih, memiliki RAM dan memori internal yang besar, memiliki daya tahan baterai yang lama, serta harga yang murah. Opini ini terbentuk karena smartphone Xiaomi memiliki fitur terbaru saat ini yaitu kamera $64 \mathrm{Mp}$, memiliki $R A M$ hingga $8 \mathrm{~Gb}$ dan memori internal hingga $256 \mathrm{~Gb}$, memiliki kapasitas baterai hingga $5500 \mathrm{mAh}$, serta harga mulai dari 700 ribuan.

Berdasarkan hal-hal yang telah dijabarkan sebelumnya, maka dapat disimpulkan bahwa ketiga karakteristik dalam gaya hidup yaitu aktivitas, minat, dan opini atau pendapat masyarakat mengenai suatu produk berpengaruh terhadap keputusan pembelian. Hal ini sesuai dengan hasil penelitian yang dilakukan oleh Somantri (2020), Halim \& Dinaroe (2019), dan Permana (2019) yang menyatakan bahwa gaya hidup berpengaruh positif dan signifikan terhadap keputusan pembelian.

Citra merek berpengaruh positif dan signifikan terhadap keputusan pembelian smartphone Xiaomi di Kabupaten Buleleng.
Jurnal Pendidikan Ekonomi Undiksha

Vol. 13 No. 1 (2021)

Hal ini sesuai dengan teori yang dikemukakan oleh Setiadi (dalam Permana, 2019) menyatakan bahwa citra terhadap merek berhubungan dengan sikap yang berupa keyakinan dan preferensi terhadap suatu merek. Konsumen yang memiliki citra yang positif terhadap suatu merek akan lebih memungkinkan untuk melakukan pembelian. Citra merek terjadi karena adanya keyakinan konsumen yang akan memperoleh kualitas yang sama jika membeli ulang pada merek yang sama dengan yang dibeli sebelumnya. Aaker dan Biel (dalam Supangkat \& Supriyatin, 2017) menyatakan bahwa indikator citra merek terdiri dari citra perusahaan, citra produk, dan citra pemakai.

Citra Perusahaan (Corporate Image) yaitu persepsi yang dihasilkan oleh konsumen terhadap perusahaan pembuat suatu produk baik barang maupun jasa. Citra perusahaan meliputi popularitas, kredibilitas, dan jaringan perusahaan. Xiaomi Corporation merupakan perusahaan dari smartphone Xiaomi memiliki citra yang baik di mata masyarakat. Melalui Xiaomi Center, perusahaan mampu memberikan corporate image yang baik dengan memberikan pelayanan yang sesuai dengan kebutuhan konsumen. Adapun pelayanan yang diberikan seperti service atau reparasi smartphone Xiaomi, mengurus klaim garansi resmi, serta pelayanan lainnya seperti informasi produk dan promo-promo yang ditawarkan.

Citra Produk (Product Image) yaitu persepsi yang dihasilkan oleh konsumen terhadap suatu produk baik barang maupun jasa. Citra produk meliputi atribut produk, manfaat untuk konsumen, penggunaannya serta jaminan. Smartphone Xiaomi memiliki atribut-atribut produk yang bermanfaat bagi konsumen. Seperti yang telah dijelaskan pada pembahasan hubungan gaya hidup terhadap keputusan pembelian smartphone Xiaomi sebelumnya, dapat diketahui bahwa smartphone Xiaomi memiliki fitur-fitur produk yang menunjang aktivitas dan minat konsumen yang kemudian menciptakan opini atau pendapat terhadap produk smartphone Xiaomi. Selain itu, smartphone 
p-ISSN : 2599-1418

e-ISSN : 2599-1426

Xiaomi juga memiliki garansi resmi yang mampu meningkatkan kepercayaan atas kualitas produk kepada konsumen.

Citra Pemakai (User Image) yaitu persepsi yang dihasilkan oleh konsumen terhadap pengguna suatu produk maupun jasa tertentu. Citra pemakai meliputi pemakai itu sendiri dan status sosialnya. Saat ini telah banyak masyarakat yang menggunakan smartphone Xiaomi dengan berbagai tipe atau variasi produk. Semakin baru tipe smartphone Xiaomi yang digunakan maka semakin canggih pula teknologi yang terdapat di dalamnya. Hal ini memberikan citra positif terhadap pemakai karena dianggap mengikuti perkembangan teknologi dalam artian tidak ketinggalan jaman.

Citra perusahaan, citra produk serta citra pemakai membentuk citra merek smartphone Xiaomi. Semakin positif citra merek berpengaruh terhadap peningkatan keputusan pembelian smartphone Xiaomi. Hal ini sejalan dengan penelitian yang dilakukan oleh Permana (2019), Hermansyur \& Aditi (2017) serta Supangkat \& Supriyatin (2017) yang menyatakan dalam hasil penelitiannya bahwa citra merek berpengaruh positif dan signifikan terhadap keputusan pembelian.

Variabel gaya hidup dan citra merek berpengaruh signifikan terhadap keputusan pembelian smartphone Xiaomi di Kabupaten Buleleng. Hal ini berarti bahwa apabila gaya hidup dan citra merek secara bersama-sama mengalami peningkatan atau penurunan akan berpengaruh terhadap keputusan pembelian.

Xiaomi memiliki berbagai fitur produk yang dapat memenuhi kebutuhan konsumen dalam beraktivitas maupun melekukan hal-hal terkait minatnya sehingga mampu membentuk opini terhadap produk smartphone Xiaomi. Semakin lengkap fitur yang dibutuhkan oleh konsumen ada pada smartphone Xiaomi maka semakin tinggi pengaruhnya terhadap keputusan pembelian konsumen. Hal ini dikarenakan dalam terdapa tiga karakteristik gaya hidup yang berpengaruh terhadap keputusan pembelian yaitu aktivitas, minat,
Jurnal Pendidikan Ekonomi Undiksha

Vol. 13 No. 1 (2021)

dan opini. Apabila ketiga karakteristik tersebut terpenuhi, maka berpengaruh terhadap keputusan pembelian.

Xiaomi juga melakukan berbagai usaha dalam membentuk citra merek yang baik di mata masyarakat. Dengan memberikan pelayanan yang baik pada Xiaomi Center mampu memberikan citra perusahaan yang baik pula. Selain itu dengan dengan berbagai fitur produk yang dimiliki serta garansi resmi yang mampu meningkatkan kepercayaan akan kualitas produk smartphone Xiaomi yang berpengaruh terhadap citra produk. Serta semakin luas pangsa pasar dan semakin canggih teknologi yang digunakan pada smartphone Xiaomi mampu memberikan pengaruh terhadap citra pemakai.

Produk yang sesuai dengan gaya hidup serta citra merek yang baik akan sangat berpengaruh terhadap keputusan pembelian suatu produk, dalam hal ini smartphone Xiaomi. Hal ini sejalan dengan hasil penelitian dari Somantri (2020) yang menyatakan bahwa gaya hidup dan citra merek secara simultan berpengaruh positif dan signifikan terhadap keputusan pembelian konsumen.

\section{SIMPULAN DAN SARAN}

Berdasarkan hasil dan pembahasan yang telah di paparkan, dapat diketahui bahwa baik secara parsial maupun secara simultan gaya hidup dan citra merek berpengaruh terhadap keputusan pembelian smartphone Xiaomi di Kabupaten Buleleng. Berikut ini merupakan simpulan dari penelitian yang telah dilakukan dapat dirinci sebagai berikut. 1) Gaya hidup berpengaruh positif dan signifikan terhadap keputusan pembelian smartphone Xiaomi di Kabupaten Buleleng. Hal ini menunjukkan bahwa setiap keputusan pembelian yang dilakukan oleh konsumen tidak terlepas dari gaya hidupnya dalam memilih dan membeli produk tertentu, sehingga semakin tinggi gaya hidup akan mampu meningkatkan keputusan pembelian. 2) Citra merek berpengaruh positif dan signifikan terhadap keputusan pembelian smartphone Xiaomi di 
p-ISSN : 2599-1418

e-ISSN : 2599-1426

Kabupaten Buleleng. Hal ini berarti bahwa apabila citra merek smartphone Xiaomi semakin positif maka akan terjadi peningkatan keputusan pembelian. 3) Gaya hidup dan citra merek berpengaruh signifikan terhadap keputusan pembelian smartphone Xiaomi di Kabupaten Buleleng. Hal ini berarti bahwa apabila gaya hidup dan citra merek secara bersama-sama mengalami peningkatan atau penurunan akan berpengaruh terhadap keputusan pembelian.

Berdasarkan hasil analisis, pembahasan, serta simpulan pada penelitian ini, adapun saran yang dapat diberikan melalui hasil penelitian ini adalah sebagai berikut. 1) Bagi perusahaan, perusahaan diharapkan lebih memperhatikan gaya hidup masyarakat masa kini maupun masa mendatang melalui riset pasar sebelum melakukan peluncuran produk baru agar produk tersebut sesuai dengan gaya hidup masyarakat. Selain itu, perusahaan diharapkan untuk meningkatkan kualitas produk dan variasi layanan untuk memperkuat citra merek smartphone Xiaomi di masyarakat. Dengan terpenuhinya gaya hidup dan di dukung dengan citra merek yang baik, akan merangsang konsumen untuk melakukan pembelian smartphone Xiaomi. 2) Bagi peneliti selanjutnya, penelitian ini hanya menggunakan variabel gaya hidup dan citra merek untuk mengetahui pengaruhnya terhadap variabel keputusan pembelian, juga tidak mengkaji hubungan antar variabel bebasnya, serta lokasi penelitian yang terbatas pada masyarakat di Kabupaten Buleleng. Bagi peneliti selanjutnya yang ingin melakukan penelitian serupa tentang keputusan pembelian diharapkan untuk menggunakan variabel lain seperti variabel atribut produk, kualitas produk, promosi, kelompok referensi, dan variabel lainnya. Diharapkan pula untuk melakukan pengkajian secara mendalam mengenai hubungan dari gaya hidup dan citra merek sehingga dapat melakukan penelitian dengan metode analisis yang berbeda, serta memilih lokasi penelitian yang
Jurnal Pendidikan Ekonomi Undiksha

Vol. 13 No. 1 (2021)

berbeda dengan penelitian ini untuk memperoleh data yang lebih bervariatif.

\section{DAFTAR PUSTAKA}

Ghozali, I. (2018). Aplikasi Analisis Multivariate Dengan Program IBM SPSS 25. Semarang: Badan Penerbit Universitas Diponegoro.

Giovinda, \& Frista. (2020). Analisis Pengaruh Harga, Promosi, dan Gaya Hidup Terhadap keputusan Pembelian pada Tiket.com. Prosiding BIEM, 1, 470-485.

Halim, H., \& Dinaroe. (2019). The Influence of Money Attitude, Lifestyle, and Personal Values on Purchase Decision of Exclusive Gadgets in Aceh. Asian Journal of Entrepreneurship and Family Business, 3(1), 13-29.

Hermansyur, H. M., \& Aditi, B. (2017). Pengaruh Kualitas produk, Citra Merek, Harga, dan Promosi Terhadap Keputusan Pembelian Mobil Merek Honda di Kota Medan. Jurnal Konsep Bisnis Dan Manajemen, 3(1), 32-43.

Kominfo. (2017). Survey Penggunaan TIK 2017 serta Implikasi Terhadap Aspek Sosial Budaya Masyarakat. Jakarta: Pusat Penelitian dan Pengembangan Aplikasi Informatika dan Informasi dan Komunikasi Publik Badan Penelitian dan Pengembangan Sumber Daya Manusia Kementrian Komunikasi dan Informatika.

Kotler, P., \& Armstrong, G. (2008). PrinsipPrinsip Pemasaran Edisi 12 Jilid 1. Jakarta: Erlangga.

Kotler, P., \& Keller, K. L. (2018). Manajemen Pemasaran Edisi 12 Jilid 1. Jakarta: PT. Indeks.

Mi.com. (2020). Making Quality Technology Accessible To Everyone. https://www.mi.com/global/about

Permana, D. I. (2019). Pengaruh Citra Merek, Harga, Word of mouth, dan Gaya Hidup Terhadap Keputusan Pembelian Motor Yamaha N-Max pada Club Yamaha N-Max Surabaya. Jurnal IImu Dan Riset Manajemen, 8(12), 124. 
Setiawan, R. (2020). Pengaruh Citra Merek Bandung: CV Andi Offset.

dan Atribut Produk Terhadap

Keputusan Pembelian Produk

Handphone Vivo Smartphone pada PT

Salim Surya Phone di Samarinda. EJournal Administrasi Bisnis, 8(1), 5564.

Setyaningsih, D. K. (2020). Pengaruh Citra Merek, Gaya Hidup Hedonis, dan Harga Terhadap Keputusan Pembelian Jilbab Rabbani (Studi pada Santriwati Pondok Pesantren Ma'had Mambaul Qur'an Munggang Bawah di Wonosobo). Journal of Economic, Business and Engineering (JEBE), 1(2), 311-318.

Somantri, B. (2020). Pengaruh Gaya Hidup dan Citra Merek Terhadap Keputusan Pembelian Produk IPhone (Studi Kasus pada Siswa dan Siswi SMAN 3 Kota Sukabumi). Cakrawala, 3(1).

Sugiyono. (2013). Metode penelitian Pendidikan Pendekatan Kualitatif dan Kuantitatif. Bandung: Alfabeta.

Supangkat, A. H., \& Supriyatin. (2017). Pengaruh Citra Merek, Kualitas Produk, Harga Terhadap Keputusan Pembelian Tas di Intako. Jurnal IImu Dan Riset Manajemen, 6(9), 1-19.

Telagawathi, N. L. W. S. (2019). Analysis of Brand Image and Promotions and their Effect on Purchase Decisions. International Conference on Tourism, Economics, Accounting, Management, and Social Science (TEAMS 19), Advances in Economics, Business and Management Research, 103.

Tjiptono, F. (2015). Strategi Pemasaran Edisi 4. Bandung: Bandung: CV Andi Offset.

Tjiptono, F., \& Diana, A. (2016). Pemasaran, Esensi \& Aplikasi. 